\title{
Causes of Student Absenteeism and School Dropouts
}

\author{
Şeyma Şahin \\ PhD Student, Ankara University, Turkey, seyymasahin@gmail.com
}

\section{Zeynep Arseven}

RA, Düzce University, Turkey, zeyneparseven@duzce.edu.tr

\section{Abdurrahman Kılıc}

Prof, Düzce University, Turkey, abdurrahmankilic@duzce.edu.tr

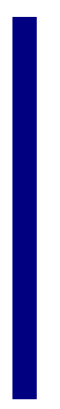
The aim of the study is to investigate the causes of student absenteeism and school dropouts at primary, secondary and high school level in Düzce Province and to develop suggestions for solving these problems. A "case study" design, which is one of the qualitative research approaches, was used in this study. The study group consisted of 64 school principals working at primary, secondary and high schools in the province center and districts of Düzce. A semi-structured interview form consisting of nine questions was used as the data collection tool. The collected data was analyzed by content analysis method. 15 main themes were formed under five categories. Certain suggestions were developed based on the findings obtained as the result of the study.

Keywords: school absenteeism, school dropouts, truancy, school principals

\section{INTRODUCTION}

Absenteeism and school dropout rates of students in a country are discussed as an important criterion that shows the quality of education in that country and this is regarded as an important predictor of the existing and future problems of the education system (Graeff-Martins et al., 2006). Absenteeism is one of the most basic indicators of to what extent the educational needs of students are met by schools. If the students are turning their back on the education they are provided, it means that we need to ask ourselves the questions of "What is wrong in this education?" and "Is something happening in our schools and classrooms that distract students from education?" (Shute \& Cooper, 2015).

Regular attendance at school is essential for the students' academic achievements, language development and social development. Students who attend school regularly can be successful in their future professional lives through achieving work-related skills such as persistence, problem-solving, and the ability to work with others to accomplish a goal (Kearney \& Graczyk, 2014). It is seen that students who attend school regularly have higher academic success, standardized test scores, graduation averages, university 
entrance rates and job opportunities (Balfanz \&Byrnes, 2012; Ferrell et al., 2013; Kearney \& Graczyk, 2014). Compared to their peers, students who don't attend school regularly have lower academic performance, limited future employment opportunities and will experience social and emotional problems in adulthood (Askeland et al., 2015; Buscha \& Conte, 2014; Nolan et al., 2013; Thornton, Darmody \& McCoy, 2013).

Absenteeism not only affects the academic progress of the student, but also influences the in-class planning of teachers and at the same time the motivations of the other students in the class (Thornton, Darmody \& McCoy, 2013). Chronic absenteeism has a significant relationship with certain dangerous behaviors such as substance abuse, violence, physical injury, suicide, showing sexually explicit behavior at an early age,pregnancy and eventual dropout (Ferrell et al., 2013; Gage et al., 2013; Kearney \& Graczyk, 2014; Nolan et al., 2013; Thornton, Darmody \& McCoy, 2013).

School dropout is defined as the failure of a student in completing the current stage of education he or she is enrolled for several reasons (Dekkers \& Claassen, 2001). In our day, societies are intensively facing school dropout problems that have personal, social and financial dimensions and trying to develop policies in order to prevent or decrease this problem (Heers et al., 2014; De Witte \& Csillag, 2014; Estevao \& Alvares, 2014). Studies show that individuals who drop out of school have more health problems, have an increased risk of involvement in crime, are obliged to work at a job with a low income (Cabus \& Witte, 2015; Carlson, 2014; Carr \& Galassi, 2012; Estevao \& Alvares, 2014; Fan \& Wolters, 2014; Lamote et al., 2013; Taş et al., 2013), live ten years shorter than the average and perform their social responsibilities such as voting in elections less compared to the others (Dockery, 2012).

Some researches examining the causes of absenteeism and dropouts are available in our country (Aküzüm et al., 2014; Altınkurt, 2008; Bayhan \& Dalgıç, 2012; Gömleksiz \& Özdaş, 2013; Haberli \& Güvenç, 2012; Özbaş, 2010; Öztekin, 2013; Sarı, 2013; Şimşek \& Şahin, 2012; Taş et al., 2013; Tayl1, 2008; Uysal, 2008; Yıldız \&Kula, 2012). When the results of these studies were analysed, it has been observed that the causes of school absenteeism and school dropouts are mostly originated from family, school and student.

\section{Aim of the Study}

The aim of this study is to present the causes of student absenteeism and school dropouts in Düzce Province and to develop some suggestions regarding the solution of these problems.

\section{METHOD}

\section{Research Model}

In the present study, "case study" design, which is one of the qualitative research approaches, was used as the research model. One of the most important characteristics of a case study, which is widely used in qualitative research, is that it enables the thorough examination of one or several cases (Yıldırım \& Şimşek, 2006). In this study, it was endeavored to conduct a thorough examination of cases of absence and dropout. 


\section{Study Group}

The study group consisted of 64 school principals who worked at primary, secondary and high schools in the province center and the districts of Düzce in the academic year of 2014-2015.

\section{Data Collection}

A semi-structured interview form consisting of nine questions was used as the data collection tool. Following the literature review, the draft interview form that was prepared by the researchers was put into its final form based on the opinion of an educational sciences expert and made ready for implementation. The semi-structured interview form was aimed to be delivered to all school principals, 64 of them filled in the interview forms and sent them back to the researchers.

\section{Data Analysis}

The data obtained from the study was analyzed by using content analysis method. The research data were coded respectively by two researchers and then the main themes were formed together by the researchers. Common themes were determined by bringing together the codes that were related to one another.

\section{Validity and Reliability}

To maintain the validity and reliability of the study; the internal consistency of the subthemes that emerged as the result of the content analysis and the internal consistency of the main themes were checked and a logical integrity was maintained. The procedures and stages of the study were defined clearly and in detail. The opinion of an expert was taken when associating the research data with the research results. The raw data of the study were saved in order to examine when needed.

\section{FINDINGS}

In this section, the causes of absenteeism and school dropouts were discussed and interpreted under five categories based on the analysis of the collected data respectively.

\section{Causes of Absenteeism and School Dropouts Originating from the Family}

The causes of absenteeism and school dropouts that originate from the family were gathered under five main themes. The main themes and sub-themes that indicate the causes of absenteeism and school dropouts that originate from the family are given in Table 1.

Table 1: Causes of absenteeism and school dropouts originating from the family

\begin{tabular}{lclcc}
\hline \multicolumn{4}{c}{ Main Theme 1: Family-Child Relationship } \\
\hline \multicolumn{1}{c}{ Absenteeism } & $f$ & \multicolumn{1}{c}{ School Dropouts } & $f$ \\
\hline Not taking care of child & 25 & Not taking care of child & 10 \\
Not wakening up child on time, not & 22 & Not establishing relations with the school & 3 \\
preparing for school & 12 & Being overly oppressive on child & 3 \\
Missing the school vehicle & 4 & Unable to have good communiation with & 3 \\
Working mothers and fathers & & child &
\end{tabular}




\begin{tabular}{|c|c|c|c|}
\hline Being overly oppressive on child & 4 & Failure to be a good role-model to child & 3 \\
\hline Not providing necessary authority on child & 3 & Accepting the failure of child & 2 \\
\hline Accepting the failure of child & 2 & Working mothers and fathers & 1 \\
\hline Not establishing relations with the school & 2 & Not providing necessary authority on child & 1 \\
\hline Not motivating child to school & 2 & Not keeping track of the child's friends & 1 \\
\hline \multicolumn{4}{|c|}{ Main Theme 2: Ignoring of Absenteeism } \\
\hline Absenteeism & $f$ & School Dropouts & $f$ \\
\hline $\begin{array}{l}\text { Family plans like family visits, shopping } \\
\text { etc. }\end{array}$ & 28 & & \\
\hline Leaving the city or town & 11 & & \\
\hline $\begin{array}{l}\text { Activities like funerals, weddings, } \\
\text { engagements, see off to soldier etc. }\end{array}$ & 8 & & \\
\hline Family choice & 7 & & \\
\hline Inviting guests & 1 & & \\
\hline \multicolumn{4}{|c|}{ Main Theme 3: Family Problems } \\
\hline Absenteeism & $f$ & School Dropouts & $f$ \\
\hline $\begin{array}{l}\text { Family problems like divorce, family } \\
\text { violence etc. }\end{array}$ & 24 & $\begin{array}{l}\text { Family problems like divorce, family } \\
\text { violence etc. }\end{array}$ & 23 \\
\hline Having someone at home in need of care & 8 & Having someone at home in need of care & 3 \\
\hline Death of parents & 1 & Death of parents & 1 \\
\hline \multicolumn{4}{|c|}{ Main Theme 4: View of Education } \\
\hline Absenteeism & $f$ & School Dropouts & $f$ \\
\hline $\begin{array}{l}\text { Failure to understand the importance of } \\
\text { education }\end{array}$ & 16 & $\begin{array}{l}\text { Failure to understand the importance of } \\
\text { education }\end{array}$ & 12 \\
\hline \multirow[t]{4}{*}{ Lack of education } & 8 & Lack of education & 10 \\
\hline & & $\begin{array}{l}\text { Not sending daughters to school for } \\
\text { religious reasons }\end{array}$ & 6 \\
\hline & & $\begin{array}{l}\text { Sending children to religious education } \\
\text { institutions }\end{array}$ & 3 \\
\hline & & Getting girls married at an early ages & 2 \\
\hline \multicolumn{4}{|c|}{ Main Theme 5: Economic Impossibilities } \\
\hline Absenteeism & $f$ & School Dropouts & $f$ \\
\hline \multirow{2}{*}{$\begin{array}{l}\text { Financial difficulties } \\
\text { Makingchildwork at homeor at } \\
\text { seasonalworks }\end{array}$} & 14 & Financial difficulties & 15 \\
\hline & 13 & Startingtowork at an early age & 7 \\
\hline Makingchildtotakecare of his siblings & 9 & $\begin{array}{l}\text { Makingchildwork at home or at seasonal } \\
\text { works }\end{array}$ & 4 \\
\hline Inabilitytoprovideforschoolsupplies & 4 & & \\
\hline Not beingabletogivepocketmoneytochild & 3 & & \\
\hline $\begin{array}{l}\text { Inabilitytoprovide a } \\
\text { suitableworkingenvironment at home }\end{array}$ & 1 & & \\
\hline
\end{tabular}

Lack of care for the child is regarded as the most important family-based cause of both absenteeism and school dropout. Working conditions of parents could decrease the time they spend for and their control over their children, and increase absenteeism and school dropout rates. It is observed that the children of families who cannot have a good communication with their children, who are highly oppressive or who have no authority on their children and have accepted the failure of their children show considerably high cases of absenteeism and school dropout.

International Journal of Instruction, January $2016 \bullet$ Vol.9, No.1 
Families may prefer not to send their children to school because of several reasons such as going shopping, funerals, weddings, going out of the city or district or having guests at home. It is considered that this case clearly presents the importance the families place on absenteeism, and hence to education.

Family problems such as divorce, domestic violence and death of a parent have a highly negative effect on the student's attendance at school. In such cases, students lack concern, love and parental control and become more inclined to show aimless attitudes such as absenteeism and school dropout.

Parents' lack of education and accordingly their disregard for education appear as an important cause of absenteeism and school dropout. According to research findings, many families think that the education of girls is not important, girls are forced to get married at an early age and kept at home to provide help with housework. Besides, it is also seen that some families take their children from mainstream schools to have them get religious education.

Poor economic situations of families play a significant role in absenteeism and then dropping out of school. Children of seasonal worker families or children that are forced to work as seasonal workers are kept away from school for a long time and this has a considerably negative effect on the children's school lives. It can be said that particularly the obligation of boys to work at a job and contribute to the economy of the family and thus beginning to work at an early age is a highly important factor in school dropout.

\section{Causes of Absenteeism and School Dropouts Originating from Administrator and Teacher Behaviors}

The causes of absenteeism and school dropout originating from administrator and teacher behaviors were gathered under four main themes. The main themes and subthemes that indicate the causes of absenteeism and school dropouts that originate from administrator and teacher behaviors are given in Table 2.

Table 2: Causes of absenteeism and school dropouts originating from administrator and teacher behaviors

\begin{tabular}{|c|c|c|c|}
\hline \multicolumn{4}{|c|}{ Main Theme 1: Administrators-Student Relationship } \\
\hline Absenteeism & $f$ & School Dropouts & $f$ \\
\hline Negative attitudes to student & 8 & Negative attitudes to student & 9 \\
\hline Being overly oppressive on student & 7 & Being overly oppressive on student & 9 \\
\hline Negative attitudes when students are late & 1 & Not paying attention to students & 2 \\
\hline \multicolumn{4}{|c|}{ Main Theme 2: Teacher-Student Relationship } \\
\hline Absenteeism & $f$ & School Dropouts & $f$ \\
\hline $\begin{array}{l}\text { Unable to make students love classes and } \\
\text { school }\end{array}$ & 15 & Being overly oppressive on student & 10 \\
\hline Negative attitudes to student & 13 & Negative attitudes to student & 10 \\
\hline Unable to make students love them & 6 & Not paying attention to students & 6 \\
\hline Being overly oppressive on student & 5 & Not giving love to students & 4 \\
\hline Not giving love to students & 4 & $\begin{array}{l}\text { Unable to make students love classes and } \\
\text { school }\end{array}$ & 2 \\
\hline
\end{tabular}




\section{Not paying attention to students}

Not recognizing students

Unable to communicate positively with parents of students

Failure to provide effective guidance to students

Saying bad words to students

Frighten of students

Success oriented approach

Forcing capacity of students
Failure to provide effective guidance to students

Frighten of students

Not concerning about psychological

problems of students

Unable to communicate positively with

parents of students

Forcing capacity of students

Not being tolerant to students

Humiliation of students

Unable to gain self-confidence to students

Unable to make students love them

Judging students

Not creating educational awareness in

students

Main Theme 3: In-Class Behaviors of the Teacher

\begin{tabular}{|c|c|c|c|}
\hline Absenteeism & $f$ & School Dropouts & $f$ \\
\hline Homework pressure & 19 & $\begin{array}{l}\text { Unable to organize effective learning } \\
\text { environment }\end{array}$ & 1 \\
\hline $\begin{array}{l}\text { Failure to provide student's participation in } \\
\text { class }\end{array}$ & 4 & $\begin{array}{l}\text { Failure to provide student's participation } \\
\text { in class }\end{array}$ & 1 \\
\hline $\begin{array}{l}\text { Unable to organize effective learning } \\
\text { environment }\end{array}$ & 2 & $\begin{array}{l}\text { Unable to make the learning environment } \\
\text { fun }\end{array}$ & 1 \\
\hline Deficiencies in classroom management & 2 & & \\
\hline $\begin{array}{l}\text { Unable to make the learning environment } \\
\text { fun }\end{array}$ & 2 & & \\
\hline Occupational inability & 1 & & \\
\hline $\begin{array}{l}\text { Not making courses in the first and last week } \\
\text { of schools }\end{array}$ & 1 & & \\
\hline
\end{tabular}
of schools

\begin{tabular}{|c|c|c|c|}
\hline Absenteeism & $f$ & School Dropouts & $f$ \\
\hline Not contacting with parents about absences & 15 & Not monitoring absenteeismrigorously & 3 \\
\hline Not monitoring absenteeismrigorously & 7 & $\begin{array}{l}\text { Not contacting with parents about } \\
\text { absences }\end{array}$ & 2 \\
\hline Not investigating the causes of absenteeism & 4 & $\begin{array}{l}\text { Not implementing the laws and } \\
\text { regulations }\end{array}$ & 1 \\
\hline The lack of sanctions of absenteeism & 2 & The lack of sanctions of absenteeism & 1 \\
\hline Not paying attention to absenteeism & 1 & Not taking precautions about absenteeism & 1 \\
\hline
\end{tabular}

Negative behaviours of directors towards the student and extremely oppressive attitudes lead students to absence and to drop out of school. Furthermore, it is observed that students who are afraid of the harsh and negative attitudes of directors when they are late to school prefer not to go to school on that day. Besides, teachers' negative and extremely oppressive attitudes towards the students come out as an important factor in the students' attendance at school.

The most important cause listed under the theme of "in-class behaviours of the teacher" was found as homework pressure. Students who do not or cannot do the assigned homework due to several reasons and are afraid of the reactions of the teacher or their peers do not want to go to school on the day of that class. Causes that stem from the teachers' understanding of education and negative in-class behaviors, decreases and 
even destroys the students' interest and attention to classroom life. This leads to absenteeism and to school dropouts in the long term.

Negligent control of absences of students, failing to contact the parents in case of absence and not investigating the causes of absences show that the necessary importance is not given to absenteeism, which leads to the increase of absences and ultimately the occurrence of school dropouts.

\section{Causes of Absenteeism and School Dropouts Originating from the School Setting}

The causes of absenteeism and school dropout originating from the school setting were grouped under two main themes. The main themes and sub-themes are given in Table 3.

Table 3:Causes of absenteeism and school dropouts originating from the school setting

\begin{tabular}{|c|c|c|c|}
\hline \multicolumn{4}{|c|}{ Main Theme 1: School Structure } \\
\hline Absenteeism & $f$ & School Dropouts & $f$ \\
\hline The lack of socio-cultural activities & 5 & The lack of socio-cultural activities & 4 \\
\hline The lack of physical structure & 2 & Extreme course load & 3 \\
\hline $\begin{array}{l}\text { Unable to make schools the center } \\
\text { of attraction }\end{array}$ & 1 & Difficulty of the courses & 1 \\
\hline Extreme course load & 1 & & \\
\hline \multicolumn{4}{|c|}{ Main Theme 2: Negative School Atmosphere } \\
\hline Absenteeism & $f$ & School Dropouts & $f$ \\
\hline Negative friendship relations & 21 & Negative friendship relations & 12 \\
\hline Negative incidents in school & 8 & Ridiculing with students & 4 \\
\hline Exclusion of students & 5 & Students' feelings of self worthless & 2 \\
\hline Peer bullying & 3 & $\begin{array}{l}\text { Inability to adapt to class because of class } \\
\text { repetition }\end{array}$ & 2 \\
\hline Students' feelings of self worthless & 2 & Exclusion of students & 1 \\
\hline \multirow[t]{4}{*}{ Accusing students unjustly } & 1 & Negative incidents in school & 1 \\
\hline & & $\begin{array}{l}\text { Failure to ensure a democratic school } \\
\text { environment }\end{array}$ & 1 \\
\hline & & Accusing students unjustly & 1 \\
\hline & & Students' insecure feelings & 1 \\
\hline
\end{tabular}

Schools fail to become interesting places for students due to reasons such as lack of sociocultural activities, insufficiency of the physical structures of schools and excessive course loads and for these reasons, students' willingness to go to school decreases. Providing children and adolescents with learning environments in which they feel themselves peaceful, happy and secure in schools where they spend an important part of their daily time is an important factor that can increase their commitment to school and education in general.

\section{Causes of Absenteeism and School Dropouts Originating from the Students}

The causes of absenteeism that originate from the student were grouped under three main themes. The main themes and sub-themes that indicate the causes of absenteeism and school dropouts originating from the student are given in Table 4. 
Table 4: Causes of absenteeism and school dropouts originating from the students

\begin{tabular}{|c|c|c|c|}
\hline \multicolumn{4}{|c|}{ Main Theme 1: Adaptation to School } \\
\hline Absenteeism & $f$ & School Dropouts & $f$ \\
\hline Not having good relations with peers & 12 & Dislike school and lessons & 14 \\
\hline Dislike school and lessons & 6 & Not having good relations with peers & 3 \\
\hline Not having good relations with teachers & 6 & $\begin{array}{l}\text { Not having good relations with } \\
\text { teachers }\end{array}$ & 2 \\
\hline Failure to adapt to school & 4 & $\begin{array}{l}\text { Not having good relations with } \\
\text { administrations }\end{array}$ & 1 \\
\hline \multicolumn{4}{|c|}{ Main Theme 2: Individual Reasons } \\
\hline Absenteeism & $f$ & School Dropouts & $f$ \\
\hline Illness & 58 & Academic failure & 8 \\
\hline Academic failure & 10 & Learning difficulties & 8 \\
\hline Psychological causes & 4 & Illness & 7 \\
\hline School phobia & 4 & Age and physical characteristics & 2 \\
\hline Examination phobia & 2 & School phobia & 1 \\
\hline Lack of self-confidence & 1 & Mental retardation & 1 \\
\hline Inability to express himself & 1 & Trying to prove himself & 1 \\
\hline Sibling jealousy & 1 & Inability to express himself & 1 \\
\hline Inseparable from family & 1 & & \\
\hline \multicolumn{4}{|c|}{ Main Theme 3: Relationships with the Environment } \\
\hline Absenteeism & $f$ & School Dropouts & $f$ \\
\hline Hanging up school (internet cafe, etc.) & 5 & Bad circle of friends & 7 \\
\hline Bad circle of friends & 4 & Bad habits (drug use, etc.) & 2 \\
\hline Bad habits (drug use, etc.) & 2 & Girlfriend-boyfriend relationship & 1 \\
\hline Girlfriend-boyfriend relationship & 1 & Being involved in a crime & 1 \\
\hline
\end{tabular}

It was found that students who cannot maintain good relationships with their friends, teachers and managers, who do not like the school and the subjects have a higher tendency to be absent from school and to drop out of school. Among individual reasons, illness is the factor that has the biggest effect on absence. Academic failure and learning disability are noticeable as highly important causes of both absence and dropping out of school. It is seen that factors such as bad circle of friends, bad habits, girl/boy relationships and going to places like internet cafes have significant effects on the students' absence and dropping out of school.

\section{Environmental Causes of Absenteesim and School Dropouts}

The environmental causes of absenteeism and school dropouts are presented under the main theme of "environmental factors" in Table 5.

Table 5: Environmental causes of absenteeism and school dropouts

\begin{tabular}{llll}
\hline \multicolumn{4}{c}{ Main Theme 1: Environmental Factors } \\
\hline Absenteeism & $f$ & School Dropouts & $f$ \\
\hline Transportation difficulties & 4 & Transportation difficulties & 3 \\
Bad weather conditions & 4 & Negative media impact & 1 \\
Negative media impact & 1 & & \\
\hline
\end{tabular}

International Journal of Instruction, January $2016 \bullet$ Vol.9, No.1 
Environmental factors were determined as the difficulty of transportation, negative weather conditions and the negative effect of the media.

\section{CONCLUSIONS}

Five categories were found in this research that causes student absenteeism and school dropouts. These categories were determined as; causes originating from the family, causes originating from director and teacher behaviors, causes originating from the school setting, causes originating from the student and environmental causes. And then 15 main themes were determined under these categories. These main themes are: familychild relationship, ignoring of absence, family problems, view of education, economic impossibilities, director-student relationship, teacher-student relationship, in-class behaviors of the teacher, attitude towards absence, school structure, negative school atmosphere, adaptation to school, individual reasons, relationships with the environment, and environmental factors.

Family-child relationship: Children of families that do not communicate with the school are absent from school more and have higher dropout risk compared to the others. Thornton, Darmody \& McCoy (2013) state that participation in parent-teacher meetings and other activities, monitoring the child's school attendance and homework supports the child's academic progress and school attendance. It is seen that the children of families who cannot have a good communication with their children, who are highly oppressive or who have no authority on their children and have accepted the failure of their children show considerably high cases of absenteeism and school dropout. Altınkurt (2008) found out that students' desire to attract the attention of their parents and parents' putting excessive pressure on the child to go to school have a high effect on the increase of absenteeism rates.

Ignoring of absenteeism: Families may prefer not to send their children to school because of several reasons such as going shopping, funerals, weddings, going out of the city or district or having guests at home. Thornton, Darmody \& McCoy (2013) state that Irish families sometimes do not send their children to school for reasons such as going on holiday.

Family problems: It is considered that cases such as divorce, domestic violence and death of a parent have a highly negative effect on the student's attendance at school. Hynes (2014) states that children who have one or both parents in jail are $79 \%$ more likely to leave school, children who lost a family member are $53 \%$ more likely to leave school, and children who are abused by a parent are $45 \%$ more likely to leave school. The presence of a family member that requires care at home is also one of the factors that affect absenteeism and school dropout.

View of education: Parents' lack of education and accordingly their disregard for education occur as an important cause of absenteeism and school dropout. Foley, Gallipoli \& Green (2014) found out that parents' giving importance to and valuation of education have positive effects on school dropout behavior. Unwillingness of parents to send girls to school for religious reasons and early marriage of girls have an important place in the causes of absenteeism and school dropout among girls. Adigüzel (2013) 
states that, reaching puberty and early marriage of girls are stated as an important causes of school dropouts among girls. Alat \& Alat (2011) point out that some families withdraw their children from school, especially the girls, to send them to Koran courses or marry them at an early age.

Economic impossibilities: Students who lack school supplies and cannot do their homework due to the lack of a suitable study environment at home do not want to go to school and are often absent from school. Again, lack of pocket money and travelling money emerges as a cause of school absenteeism. Studies (Balfanz \& Byrnes, 2012; Koepke, Kupczynski \& Holland, 2011; Nolan et al., 2013; Petrick, 2014; Taş et al., 2013; Uysal, 2008)show that chronic absenteeism and school dropouts are highly common among students who come from low-income families. It can be said that particularly the obligation of boys to work at a job and contribute to the economy of the family are important factors in school dropout. In their study, Haberli and Güvenç (2012) found out that factors emerging from the family such as the obligation of students to help their parents at home, look after their younger siblings and work and bring money home have significant effects on their absence from school. According to Tayli (2008), working part-time during holidays and the school season has an increasing effect on the students' motivations and is suggested as an effective way of getting ready for their future roles in life. However, students who work at full-time jobs and under heavy working conditions have a higher possibility to drop out of school.

Director-student relationship: Negative behaviors and extremely oppressive attitudes of administrator towards students lead the students to absenteeism and drop out of school. According to a study by Bayhan \& Dalgıç (2012), weak communication of students with the administrators within the period they attend school is a factor that has a negative effect on the students' success and their decision to drop out of school.

Teacher-student relationship: Considering that students spend a large part of their time in communication with their teachers, it is obvious that the social and emotional support that teachers provide to students is highly important. In their study, Shute \& Cooper (2015) state that students sometimes go to school and then skip some classes during the day and such cases are twice more than cases of skipping whole school days. This finding shows the importance of the factor of liking the teacher and the subject.

In-class behaviors of the teacher: Causes originating from the negative in-class behaviors of teachers, who are the operators of the education system, decreases and even destroys the students' interest and attention to classroom life. This leads to absenteeism and to school dropouts in the long term. Strand \& Granlund (2014) state that approximately three-quarters of all absenteeism in Sweden involve interconnected issues, such as boredom and stressful relationships with teachers. Homework emerges as a highly important factor that affects the students' attendance at school. Students who do not or cannot do the assigned homework due to several reasons do not want to go to school on the day of that class. In the study by Altınkurt (2008), it was found that $31.6 \%$ of the 308 students who participated in the study were absent from school when they did not do their homework. 
Attitude towards absenteeism: Negligent control of student absenteeism, failing to contact the parents in case of absenteeism and not investigating the causes of absenteeism lead to the increase of absenteeism and the occurrence of school dropouts. In their studies, Uysal (2008) states that there are no detection on young people who drop out of school and dropouts are not even asked about their reasons for leaving school.

School structure: Lack of socio cultural activities, insufficiency of the physical structures of schools and excessive course loads emerged as causes of absenteeism and school dropouts. According to Gömleksiz \& Özdaş (2013), as the students' level of satisfaction from the education system and the school increases, their tendency to drop out of school decreases. In their study, Aküzüm et al.(2014) state that the insufficiency of the physical facilities of the school is also an important cause of absenteeism.

Negative school atmosphere: Student's seeing oneself worthless, being an object of derision, exclusion, being unjustly accused and feeling insecure were found as causes of absenteeism and school dropouts. According to Lamote et al.(2013) and Strand \& Granlund (2014), the sense of belonging to school, trust in school, trust in the staff, commitment to various school activities decrease absenteeism rates, the negative aspects of the school setting may cause stress in students and lead to dropout. According to Sar1 (2013), when students view themselves as an important constituent of school, their academic success increases and their probability of dropping out of school decreases.

Adaptation to school: Students who cannot establish good relationships with their friends, teachers and school administration, who do not like the school and the subjects have a higher tendency to be absent from school and to drop out of school. Also in a study by Fan and Wolters (2014), it is stated that one of the most important causes of dropping out of school is being reluctant to go to school and disliking school. Taş et al. (2013) state the individual causes of school dropouts as the difficulty of the school curriculum and reluctance towards school.

Individual reasons: Among the individual causes of absenteeism, illness is the factor that has the highest effect on absenteeism. Y1ldiz and Kula (2012) also found that the biggest cause of students' absence from school was health problems. Academic failure and learning disabilities emerge as a highly important cause of both absenteeism and school dropout. Strand \& Granlund(2014) state that learning disabilities are highly common among student groups with high absenteeism rates. Besides, according to Nolan et al. (2013), students enrolled in special education are under a higher risk of absenteeism compared to other students.

Relationships with the environment: Students' friendship with their peers is one of the most important factors that affect their attendance at school. Altınkurt (2008) states that causes such as wanting to meet girl/boyfriends, trying to be accepted by their friends, the pressure of friends who are truant and wanting to go to internet cafes have a highly significant effect on the absenteeism of students from school.

Environmental factors: Environmental factors that affect student absenteeism and school dropouts were determined as the difficulty of transportation, negative weather 
conditions and the negative effect of the media. Özbaş (2010) points out that the distance of the location where the students live to the school and negative climate conditions are the factors that cause absenteeism. In their study, Gömleksiz \& Özdaş (2013) also state that negative outcomes of seasonal climate conditions also cause students to be absent from school.

The following suggestions were developed based on the results of the present study:

i. Causes of absenteeism should be determined on the basis of school and individual and solutions should be provided accordingly. Regarding solutions, rather than sanctions for punishment, precautions aiming at counseling services should be prioritized.

ii. Issues concerning the detection of students who are absent from school and have a tendency to drop out of school, the investigation of the causes of absenteeism and the creation of solutions should be primarily the responsibility of school counseling services. Besides, absenteeism monitoring should be done by the school counseling service on a daily, weekly and monthly basis.

iii. Solutions should be created in cooperation with the Ministry of Family and Social Policies for students who are absent or drop out due to economic reasons.

iv. Students and administrator should avoid behaviors that distract the students from school. Students should be helped to enjoy school and a positive school atmosphere that enhances the students' commitment to school should be created. If necessary, in-service training programs should be organized for this aim.

v. Elective courses should be varied depending on the interests and needs of students and suitable environments for these courses should be prepared at schools. The number of social and sportive activities at schools should be increased; schools should be turned into centers of attraction.

vi. Students should be provided opportunities to realize themselves, their anxieties of failure should be tried to be prevented.

vii. Cooperation between the school and the family should be maintained and the awareness of families regarding the attendance at school should be raised.

viii. Further larger-scale quantitative studies should be conducted on absenteeism and school dropouts. 


\section{REFERENCES}

Adıgüzel, A. (2013). Kız çocuklarının okullulaşma engelleri ve çözüm önerileri (Şanlıurfa örneği). Ekev Akademi Dergisi, 17(56), 325-344.

Aküzüm, C., Tan, Ç., Yavaş, T. ve Uçar, M. B. (2014). İlköğretim kurumu ögrencilerinin devamsızlı ve okul terki nedenleri. Bilimin Işı̆̆ında Eğitimsel Liderlik Üzerine Uluslararası Konferans, Siirt.

Alat, Z. \&Alat, K. (2011). A qualitative study of parental resistance to girls' schooling. Educational Sciences: Theory \& Practice, 11(3), 1369-1373.

Altınkurt, Y. (2008). Öğrenci devamsızlıklarının nedenleri ve devamsızlığın akademik başarıya olan etkisi. Dumlupınar Üniversitesi Sosyal Bilimler Dergisi, 20, 129-142.

Askeland, K. G., Haugland, S., Stormark, K. M., Boe, T., \& Hysing, M. (2015). Adolescent school absenteeism and service use in a population-based study. $B M C$ Public Health, 15, 1-9.

Balfanz, R. \&Byrnes, V. (2012). The importance of being in school: A report on absenteeism in the nation's public schools. Education Digest: Essential Readings Condensed for Quick Review, 78(2), 4-9.

Bayhan, G. \&Dalgıç, G. (2012). Liseyi terk eden öğrencilerin tecrübelerine göre okul terki. İnönü Üniversitesi Eğitim Fakültesi Dergisi, 13(3), 107-130.

Buscha, F. \&Conte, A. (2014). The impact of truancy on educational attainment during compulsory schooling: A bivariate ordered probit estimator with mixed effects. The Manchester School, 82(1), 103-127.

Cabus, S. J.\&Witte, K. (2015). The effectiveness of active school attendance interventions to tackle dropout in secondary schools: A Dutch pilot case. Empirical Economics, 49(1), 65-80.

Carlson, C. L. (2014). Dropout factories and the vaccination approach: The impact of the dropout rate on the economy and the need for effective literacy instruction. SRATE Journal, 23(2), 1-7.

Carr, C. V. \&Galassi, J. P. (2012). The role school counselors believe they should adopt in dropout prevention. Journal of School Counseling, 10(1), 1-34.

Dekkers, H. \&Claassen, A. (2001). Dropouts - disadventeged by defination? A study of the perspective of early school leavers. Studies in Educational Evaluation, 27, 341-354.

De Witte, K. \&Csillag, M. (2014). Does anybody notice? On the impact of improved truancy reporting on school dropout.Education Economics, 22(6), 549-568.

Dockery, D. J. (2012). School dropout indicators, trends, and interventions for school counselors. Journal of School Counseling, 10(12), 1-33. 
Estevao, P. \&Alvares, M. (2014). What do we mean by school dropout? Early school leaving and the shifting of paradigms in school dropout measurement. Portuguese Journal of Social Science, 13(1), 21-32.

Fan, W. \&Wolters, C. A. (2014). School motivation and high school dropout: The mediating role of educational expectation. British Journal of Educational Psychology, $84,22-39$.

Ferrell, E. W., Nance, C. N., Torres, A. L., \&Torres, S. M. (2013). Using participatory action research to address absenteeism. Action Learning: Research and Practice, 11(2), 201-214.

Foley, K., Gallipoli, G., \&Green, D. A. (2014). Ability, parental valuation of education, and the high school dropout decision. The Journal of Human Resources 49(4), 906-942.

Gage, N. A., Sugai, G., Lunde, K., \&DeLoreto, L. (2013). Truancy and zero tolerance in high school: Does policy align with practice?.Education and Treatment of Children, 36(2), 117-138.

Gömleksiz, M. N. \&Özdaş, F. (2013). Öğrenci devamsızlıklarının eğitim denetmenlerinin görüşlerine göre değerlendirilmesi. Elektronik Sosyal Bilimler Dergisi, 12(47), 106-124.

Graeff-Martins, A. S., Oswald, S., Comassetto, J. O., Kieling, C., Goncalves, R. R., \&Rohde, L. A. (2006). A package of interventions to reduce school dropout in public schools in a developing country. European Child and Adolescent Psychiatry, 15(8), 442-449.

Haberli, M. \&Güvenç, M. F. (2012). Ortaokul öğrencilerinin cinsiyet değişkeni bağlamında devamsızlık nedenleri. Insan ve Toplum Bilimleri Araştırmaları Dergisi, l(4), 149-166.

Heers, M., Van Klaveren, C., Groot, W., \&Van den Brink, H. M. (2014). The impact of community schools on student dropout in pre-vocational education. Economics of Education Review, 41, 105-119.

Hynes, M. (2014). Don't call them dropouts: Understanding the experiences of young people who leave high school before graduation. A Report from America's Promise Alliance, 1-72.

Kearney, C. A. \&Graczyk, P. (2014). A response to intervention model to promote school attendance and decrease school absenteeism. Child Youth Care Forum, 43, 1-25.

Koepke, G., Kupczynski, L., \&Holland, G. (2011). Instructional expenditures and dropout rates of special populations in Texas high schools. US-China Education Review, 6, 862-867.

Lamote, C., Speybroeck, S., Van Den Noortgate, V., \&Van Damme, J. (2013). Different pathways towards dropout: The role of engagement in early school leaving. Oxford Review of Education, 39(6), 739-760. 
Nolan, J. R., Cole, T., Wroughton, J., Clayton-Code, K. P., \&Riffe, H. A. (2013). Assessment of risk factors for truancy of children in grades K-12 using survival analysis. Journal of At-Risk Issues, 17(2), 23-30.

Özbaş, M. (2010). İlköğretim Okullarında Öğrenci Devamsızlığının Nedenleri. Ĕğitim ve Bilim, 35(156), 32-44.

Öztekin, Ö. (2013). Lise Öğrencilerinin Devamsızlık Nedenlerinin İncelenmesi. Yayınlanmamış yüksek lisans tezi, Eskişehir Osmangazi Üniversitesi, Eskişehir.

Petrick, D. L. (2014). School dropouts: Poverty and consequences for society. Insights to a Changing World, 4, 127-136.

Sarı, M. (2013). Lise öğrencilerinde okula aidiyet duygusu. Anadolu Üniversitesi Sosyal Bilimler Dergisi, 13(1), 147-160.

Shute, J. W. \&Cooper, B. S. (2015). Understanding in-school truancy. Phi Delta Kappan, 96(6), 65-68.

Strand, A. M. \&Cedersund, E. (2013). School staff's reflections on truant students: A positioning analysis. Pastoral Care in Education, 31(4), 337-353.

Strand, A. M. \&Granlund, M. (2014). The school situation for students with a high level of absenteeism in compulsory school: Is there a pattern in documented support? Scandinavian Journal of Educational Research, 58(5), 551-569.

Şimşek, Ş. ve Şahin, S. (2012). İlköğretim ikinci kademe öğrencilerinde okulu bırakma eğilimi ve nedenleri (Şanlıurfa ili örneği). Abant İzet Baysal Üniversitesi Eğitim Fakültesi Dergisi, 12(2), 41-72.

Taş, A., Selvitopu, A., Bora, V.,\&Demirkaya, Y. (2013). Meslek lisesi öğrencilerinin okul terk nedenleri. Kuram ve Uygulamada Ĕgitim Bilimleri, 13(3), 1551-1566.

Taylı, A. (2008). Okulu bırakmanın önlenmesi ve önlemeye yönelik uygulamalar.Abant İzzet Baysal Üniversitesi Eğitim Fakültesi Dergisi, 8(1), 91-104.

Thornton, M., Darmody, M., \&McCoy, S. (2013). Persistent absenteeism among Irish primary school pupils. Educational Review, 65(4), 488-501.

Uysal, A. (2008). Okulu bırakma sorunu üzerine tartışmalar: Çevresel faktörler. Milli Ĕ̈itim, 178, 139-150.

Yıldırım, A. \&Şimşek, H. (2006). Sosyal Bilimlerde Nitel Araştırma Yöntemleri(5. Baskı). Ankara: Seçkin Yayıncılık.

Yıldız, M. ve Kula, K. Ş. (2012b). Öğretmenlerin öğrenci devamsızlıkları hakkındaki görüşleri. DPUJSS, 32(2), 19-28. 


\section{Turkish Abstract}

\section{Öğrenci Devamsızlıkları ve Okul Terklerinin Nedenleri}

Araştırmanın amac1; Düzce ilinde ilkokul, ortaokul ve lise düzeyindeki öğrenci devamsızlıklarının ve okul terklerinin sebeplerini araştırmak ve bu sorunların çözümüne ilişkin öneriler geliştirmektir. $\mathrm{Bu}$ araştırmada; nitel araştırma yaklaşımlarından olan "durum çalışması" deseni kullanılmışıı. Araştırmanın çalışma grubunu; Düzce il merkezinde ve ilçelerinde, ilkokul, ortaokul ve lise düzeyindeki okullarda görev yapan 64 okul müdürü oluşturmaktadır. Veri toplama aracı olarak dokuz sorudan oluşan yarı yapılandırılmış görüşme formu kullanılmıştır. Veriler, içerik analizi yöntemi ile analiz edilmiştir. Öğrencilerin devamsızlık ve okul terki sebepleri olarak; beş ana başlık altında toplam 16 ana tema oluşturulmuştur. Araştırma sonunda ulaşılan sonuçlara göre bazı öneriler geliştirilmiştir.

Anahtar Kelimeler: devamsızlık, öğrenci devamsızlıkları, okul terki, okulu asma, okul müdürleri

\section{French Abstract}

\section{Les causes d'Absentéisme d'Étudiant et Licenciés Scolaires}

La permission des étudiants pour se servir d'occasions éducatives se nivelle tout au plus est une des tâches les plus importantes d'écoles. Une des conditions pour réaliser cette fonction doit maintenir(entretenir) la présence à l'école régulière. Le but de l'étude est d'examiner les causes d'absentéisme d'étudiant et des licenciés scolaires au niveau de lycée et primaire, secondaire dans la Province Düzce et développer des suggestions pour résoudre ces problèmes. Un modèle "d'étude de cas", qui est une des approches de recherche qualitatives, a été utilisé dans cette étude.Le groupe d'étude a consisté en 64 principaux scolaires travaillant aux lycées et primaires, secondaires dans le centre de province et les quartiers de Düzce. Une forme(un formulaire) d'entretien(interview) semi-structurée consistant de neuf questions a été utilisée comme l'outil de collecte de données. Les données rassemblées ont été analysées par la méthode d'analyse de contenu. 16 thèmes principaux ont été formés sous cinq sujets principaux. De certaines suggestions ont été développées basées sur les découvertes obtenues comme le résultat de l'étude.

Mots Clés: absentéisme, absentéisme scolaire, licenciés scolaires, absence injustifiée, principaux scolaires

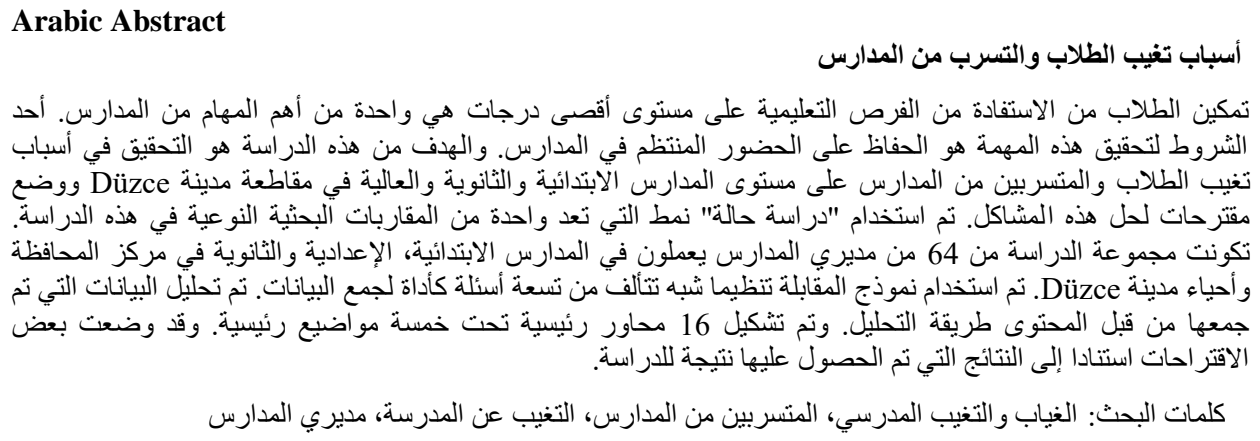

